survey of a limited area of West African rain-forest comparable with those previously made by $\mathrm{Mr}$. Richards in Guiana and Sarawak. This meant a study of the floristic composition and structure of various types of primary forest on one hand, and a study of soil and micro-climatic conditions on the other. In addition, Mr. W. J. Fletcher Cambell made a general soil survey. Mr. Ross studied the succession of secondary forest on old farms and $\mathrm{Mr}$. G. C. Evans worked on the growth, transpiration and assimilation of two species of undergrowth shrubs. The base camp was about five miles from Akilla in the Shasha Forest Reserve, Ijebu Province, and the area worked was mostly within a radius of five miles from the camp. Four months were spent here, and a visit, via the creeks, was made for a fortnight to Nikrowa in the Okomu Forest Reserve, Benin Province, where the rain-forest is said to be the finest in Nigeria. Collecting was mainly incidental to ecological work. The specimens are particularly rich in forest trees, and special attention was paid to Bryophytes. It was possible to fix a hygrothermograph in a tree top eighty feet from the ground in primary forest and to take daily readings over a period of several weeks. A mud and bamboo laboratory was built with a dark room quite efficient for working with panchromatic plates.

THE collection of plants made by Mr. P. M. Synge on the British Museum Expedition to Uganda and Kenya has been received; it contains 1,231 numbers. Mr. Synge's main object was the study of vegetational zones in the higher parts of the East African mountains and the environmental factors influencing them. Particular attention was paid to the arborescent Senecios, and a long series was collected. Some observations were made on humidity and temperature in the higher zones, but a complete record could not be obtained. Dr. Taylor made the main collections on the joint visits to the Aberdare Mts. and Birunga Mts. Three visits were made to Mt. Elgon and one to Mt. Kenya, while the Nyamgasani valley on the south side of Ruwenzori was ascended and collections made up to the limit of vegetation. Some water plants and algæ were collected from the Nyamgasani lakes : a little collecting was also done in the papyrus swamp around Lake Kioga.

\section{Archæological Exploration in Africa}

Prof. Leo Frobenius, president of the Frankfurt Research Institute for Cultural Morphology, who has recently returned from his twelfth expedition to Africa, claims, it is said, that the results of his explorations in the Libyan Desert and the Sudan have now established the validity of his theories of the origin and direction of diffusion of the periods, or phases, which he distinguishes in the history of civilisation. It will be remembered that Prof. Frobenius, working on the material which he has been engaged in collecting in Africa for nearly thirty years, has not only produced an elaborate classification and scheme of distribution of the main forms of culture in that continent, but has also put forward certain views as to their historical development and affiliations. In an interview with the correspondent of The Times, which appears in the issue of July 31 , Prof. Frobenius is reported as saying that he has now discovered in the Neolithic of the Sudan, the period in which agriculture and the domestication of animals first appear, the missing, but essential, link in the chain of evidence joining prehistoric to historic cultures. It is further reported that, since October last, a staff of twenty research workers attached to the Institute and distributed from Scandinavia to Southern Rhodesia, including France, Spain, Italy, North Africa, Abyssinia and Arabia, has been engaged in filling in gaps in the evidence and adding details to the chart of cultural distributions, which is now approaching completion.

Further particulars are now to hand of an archæological discovery in Tanganyika reported early in July. According to a dispatch from Nairobi in The Times of August 1, Commander Nino del Grande, leader of an expedition collecting snake poison for the preparation of a snake-bite serum, camped for five days on the site of the ancient city discovered near Nguruka. He reports that the city is four and a half miles long by one and a half miles broad and is constructed terrace-wise on the wall of the Great Rift escarpment. Remains of houses, estimated to number four thousand, were found. Each had three or four rooms and stone walls four feet in thickness. Large stone tombs, one containing a skeleton, were found in the valley below. It is given as the opinion of Commander del Grande that no very high antiquity is to be assigned to these remains. It is thought that they may be about five hundred years old and the work of an advanced tribe, possibly the ancestors of the Wambulu now living some fifty miles away. The site is being examined by Dr. L. S. B. Leakey, whose verdict on the relation of these remains to other vestiges of stone structures found in various parts of East Africa should be of signal importance for the cultural history of the southern half of the continent.

\section{Excavations in the Fens}

THE importance of intensive exploration of the Fens, which led to the formation of the Fenland Research Committee at Cambridge, under the presidency of Prof. A. C. Seward, has already been referred to in these columns. Some of the results already obtained are now on exhibition at the British Museum, Bloomsbury, at the head of the main staircase. The sites selected are mostly between March and Mildenhall, and more or less connected with the Ouse, Cam and Bedford Rivers, where the post-glacial period is represented by peat, clay and silt, in which a sequence of human occupations can be traced, while light is further thrown on land movement and forest development. Waterways and promising sites have been traced by surveying on the ground and from the air, and an interesting feature is the occupation in Roman times of what used to be river banks but are now parallel mounds flanking slight depressions, in which shrunken rivers originally flowed. The contraction of the peat 
has left these banks in relief, and the amount of this wastage is indicated by the Holme post, which proves that Whittlesea Mere is about $11 \mathrm{ft}$. lower than in 1848. The co-operation of workers in many fields has been secured, and much attention given to the botany, geology and zoology of the region, which is linked to North Germany and Scandinavia by its foraminifera and tree-pollen, to say nothing of changes in relation to sea-level. The work supervised by Dr. Grahame Clark in association with Mr. C. W. Phillips and Major Fowler has been rendered more difficult by the presence of water in the deeper cuttings; but funds have been provided, mainly by the Percy Sladen Memorial Fund, and the present exhibition, which will be open at least two months, will reveal to a larger public the potentialities of the Fens as a field of research in various branches of science.

\section{Iron Age Site on the Sussex Weald}

A FURTher addition to the sites of industrial activity in Sussex in later prehistoric and Roman times, for which archæologists are indebted to the activity in investigation of $\mathrm{Mr}$. S. E. Winbolt, is made by the discovery of an Early Iron Age camp on the Weald in Piper's Copse, one and a quarter miles east of North Chapel, West Sussex. The situation is remote and the discovery was due to the fact that a fox had dug its earth in a dry place where a small iron smelting hearth had been constructed in the inner slope of a bank. This was found on investigation to be the north-west end of an enclosure formed by a bold bank and deepish ditch, in good condition, except on the south-east, where an attempt had been made at levelling. The dimensions of the camp, Mr. Winbolt states in a communication to The Times of August 5, are a little more than $300 \mathrm{ft}$. by $270 \mathrm{ft}$. outside measurement, the inner area comprising about $1 \frac{1}{4}$ acres. The height of the rampart, where best preserved, is $14 \mathrm{ft}$. from the bottom of the ditch. Two points of special interest arise in connexion with this discovery. The camp lies on the Wealden level (c. $120 \mathrm{ft}$.) and although Early Iron Age camps are known on heights fringing the Weald, such as at Holmbury and Hascomb, Saxonbury and Dry Hill, this is the first to be recorded at the Wealden level. The second point of interest is its date and purpose. These are fixed by red burnt material, charcoal, nodules of local iron ore and five fragments of La Tène iii pottery, as well as by many big lumps of iron ore lying near by. The site lies about two miles from the eastern slope of Blackdown near $\mathbf{a}_{\mathbf{a}}$ stream flowing into the Arun and is in the middle of a country rich in iron ore of a moderate quality, where iron furnaces and forges of late medieval date abound, as, for example, at Mitchell Park, Shillinglee, Ebernoe and Roundwyck. Mr. Winbolt points to this as a further instance of the previous existence of Iron Age and Roman iron workings where medieval and Tudor workers are found.

\section{Science and Culture: A new Indian Monthly}

IT was anticipated by the founders of the Indian Science Congress that the Congress would stimulate in India an interest in science and in scientific research. At the time of its formation, the reforms in Indian university education resulting from the recommendations of the Curzon Commission were becoming effective and the universities were beginning to be centres of research. The spirit of scientific inquiry grew during the War period, and if the formation of scientific societies and the issue of scientific journals are to be regarded as criteria of increased interest in science, the hopes of the founders of the Congress have been fulfilled. There are in existence a number of specialist societies, the most recent addition being a Physical Society, and we referred recently $(135,410,441$; March 16,1935$)$ to the foundation of the National Institute of Sciences of India with its affiliated academies, the Asiatic Society of Bengal, the U.P. Academy of Sciences (Allahabad), and the Indian Academy of Science (Bangalore). In so large a country as India it is natural that there should be more than one academy, but the choice of names for these bodies is not happy and is likely to cause confusion in references to their publications.

THE more general aspects of science have in the past been dealt with by the weekly periodical Current Science, and we have now received the first issue of a monthly journal, Science and Culture, published by a non-profit corporation in Calcutta. The object of this periodical "is the dissemination of scientific knowledge amongst the public and advocacy of its application to all walks of life as far as practicable". The first issue contains a number of valuable articles the majority of which deal with topics"of local interest, but the lecture by Prof. M. N. Saha "Ultimate Constituents of Matter" will attract a wider public. There are, in addition, reviews of books and a correspondence column. The latter, containing preliminary accounts of scientific investigations, seems scarcely in keeping with the other contents. These 'letters to the editor' would have appeared more suitably in Current Science. We welcome this new periodical, and if the high standard of the first number be maintained its success is assured.

\section{British Empire Naturalists' Association in Jersey}

IN the official report of the summer meeting of the British Empire Naturalists' Association in Jersey, Mr. Leslie Beckett, honorary organising secretary of the Association, states that many rare plants and birds were observed. Particularly was the island fruitful in flora, and of the more interesting examples noted, mention is made of many plants rare or unknown in England but quite well established and safe in Jersey ; for Jersey is the northern limit of many Continental and North African plants. The English or five-spotted catchfly (Silene gallica) was found in profusion nearly everywhere, and near Crabbe, the party found the rare variety, quinquevulnera, which few of the botanists present had seen before. One party found a big patch of the Jersey bugloss (Echium plantagineum) between St. Brelades and Corbière. On the sand-dunes near Le Pont was found the rare yellow broomrape (Orobanche ritro) which is not found elsewhere between this 